\title{
A VOXEL-MAN Tempo 3D virtuálisvalóság-szimulátor alkalmazása a sziklacsont sebészetében
}

\author{
Perényi Ádám dr..$^{{ }^{*}}$ - Posta Bálint dr. ${ }^{1^{*}}$ - Szabó Linda dr. ${ }^{1}$ \\ Tóbiás Zoltán dr. ${ }^{1}$ - Dimák Balázs ${ }^{1}$ - Nagy Roland ${ }^{1}$ - Jónás Gyöngyi² \\ Bere Zsófia dr. ${ }^{1}$. Kiss József Géza dr. ${ }^{1}$ \\ Rovó László dr. ${ }^{1}$. Csanády Miklós dr. ${ }^{1}$ \\ 'Szegedi Tudományegyetem, Általános Orvostudományi Kar, Fül-Orr-Gégészeti és Fej-Nyaksebészeti Klinika, \\ Szeged \\ ${ }^{2}$ Szegedi Tudományegyetem, Általános Orvostudományi Kar, Orvosi Készségfejlesztési Központ, Szeged
}

Bevezetés: Az emberi sziklacsont a halántékcsont része, egy bonyolult és változatos anatómiai felépítésű struktúra. A sziklacsonton végzett beavatkozások előtt, a mútéti szövődmények megelőzése érdekében, nélkülözhetetlen a biztos anatómiai tudás és kézügyesség megszerzése, valamint az egyes mútéti lépések és mozdulatok begyakorlása. A VOXEL-MAN Tempo 3D fül-orr-gégészeti szimulátor a virtuális valóság és a robotika alkalmazásával nyújt gyakorlási lehetőséget.

Célkitüzés: A Szegedi Tudományegyetem 2019-ben VOXEL-MAN fül-orr-gégészeti szimulátort helyezett üzembe az Orvosi Készségfejlesztési Központban. A cikk fül-orr-gégész szakorvos szerzői a VOXEL-MAN Tempo szimulátor megismerését követően bemutatják a készüléket, és megfogalmazzák a szimulátorral végzett beavatkozásokkal szemben támasztott igényüket.

Módszer: A szerzők a megfogalmazott szempontoknak megfelelően értékelik a VOXEL-MAN Tempo szimulátort, és meghatározzák, milyen szerepet szánnak neki a gyakorlati képzésben.

Eredmények: A szimulátor virtuálisan, mégis valósághúen mutatja meg a sziklacsont anatómiai viszonyait, a fontos anatómiai struktúrák valós térbeli elhelyezkedését és egymástól, illetve a sebészi eszköztól mért távolságát. A rendszer lehetővé teszi a fülműtétek valósághű elvégzését (kétkezes csontmunka fúróval és szívóval, vérzés szimulálása) taktilis visszacsatolással. Az egy- vagy kétkezes feladatokkal fejleszthetjük a sebészi készségeket. A fülmútétek csontmunkája reprodukálható módon elvégezhető valódi beteg halántékcsontjáról készített rutin, nagy felbontású komputertomográfiás vizsgálat anyagából.

Következtetés: Tapasztalataink alapján a szimulátor kiválóan alkalmas az egyes mútéti lépesek begyakorlására. A jövőben fontos szerepet szánunk a virtuális rendszernek a fül-orr-gégészeti graduális és a fülsebészeti posztgraduális képzésben.

Orv Hetil. 2021; 162(16): 623-628.

Kulcsszavak: virtuális valóság, mütéti szimulátor, érzés és látvány megjelenítése, halántékcsontfúrás, gyakorlat, tanulási ütem, mútéti tervezés

\section{Application field of VOXEL-MAN Tempo 3D virtual reality simulator in surgery of pars petrosa of temporal bone}

Introduction: The pars petrosa of the human temporal bone is a structure of complex and diverse anatomy. Prior to surgical interventions, in order to prevent surgical complications, it is essential to acquire sound anatomical knowledge and dexterity as well as to practice each surgical step and movement. The VOXEL-MAN Tempo 3D simulator uses virtual reality and robotics to provide an opportunity to practice.

Objective: In 2019, the University of Szeged installed a VOXEL-MAN Virtual Reality simulator at the Medical Skills Development Center. After learning about the VOXEL-MAN Tempo simulator, the authors present the device and articulate their need for interventions with the simulator.

Method: The VOXEL-MAN Tempo simulator is evaluated according to the formulated criteria and the role assigned to it in the practical training is determined.

*Mindkét szerző azonos mértékben vett részt a közlemény elkészítésében. 
Results: The simulator shows the anatomical structure of the temporal bone virtually, yet realistically, the real spatial location of the important anatomical structures and their distance from each other and from the surgical instrument. The system allows ear surgery to be performed realistically (two-handed bone work with a drill and suction) with tactile (vibration) and visual (bleeding) feedback. One can improve surgical skills with one- or two-handed tasks. Bone work in ear surgeries can be performed in a reproducible manner from routine, high-resolution computer tomography of the temporal bone of a real patient.

Conclusion: With reference to our experience, the simulator is excellent for practicing each surgical step. In the future, we intend to use this virtual system in undergraduate and postgraduate training in otolaryngology.

Keywords: virtual reality, surgical simulator, haptic and visual rendering, temporal bone drilling, training, learning curve, preoperative planning

Perényi Á, Posta B, Szabó L, Tóbiás Z, Dimák B, Nagy R, Jónás Gy, Bere Zs, Kiss JG, Rovó L, Csanády M. [Application field of VOXEL-MAN Tempo 3D virtual reality simulator in surgery of pars petrosa of temporal bone]. Orv Hetil. 2021; 162(16): 623-628.

(Beérkezett: 2020. szeptember 10.; elfogadva: 2020. november 3.)

\section{Rövidítések}

$3 \mathrm{D}=($ three-dimensional $)$ háromdimenziós; $\mathrm{CT}=($ computed tomography) komputertomográfia; EFOP = Emberi Erőforrás Fejlesztési Operatív Program; MRI = (magnetic resonance imaging) mágnesesrezonancia-képalkotás; SZTE = Szegedi Tudományegyetem

Az emberi sziklacsont (a halántékcsont része, pars petrosa ossis temporalis) anatómiája rendkívül bonyolult és változatos. A sziklacsonton végzett beavatkozások, mint amilyenek a középfülmútétek is, súlyos szövődményekkel járhatnak. Ezért nélkülözhetetlen a biztos anatómiai tudás, a finommotoros kézügyesség és az egyes mútéti lépések és mozdulatok begyakorlása. Mindezek hiányában akár életveszélyes szövődményt (a sinus sigmoideus falának jelentős vérzéssel járó sérülése vagy a tegmen mastoideum agyvízcsorgást vagy koponyaûri fertőzést okozó sérülése) vagy olyan szövődményeket okozhat az operáló orvos, amelyek átmenetileg vagy tartósan és jelentős mértékben ronthatják az életminőséget: létrejöhet az arcideg perifériás részének bénulása, a chorda tympani ízérzészavart okozó sérülése, a halló- és egyensúlyszerv szédülést és/vagy sensorineuralis hallásvesztést okozó sérülése, a hallócsontok vezetéses hallásvesztést okozó sérülése. A páciensek biztonságos és a lehető legjobb eredményt célzó ellátása érdekében a képzőhelyeknek magas színvonalú elméleti és gyakorlati képzést kell biztosítaniuk orvosgyakornokaik számára, mielőtt azok a mútéti tevékenységüket kezdetben felügyelettel megkezdhetik, majd önállóan végezhetik.

A fülsebészeti gyakorlatok arany standardjának a humán kadáversziklacsontokon végzett gyakorlatokat tartjuk $[1,2]$. Hagyományos kadávergyakorlatok esetén az elhunytból eltávolított és formalinban tartósított vagy friss halántékcsonton a műtőben használatos kézimúszerek és -fúró alkalmazásával végezhetünk csont- és lágy- rész-munkát mikroszkópos vagy endoszkópos vizualizáció mellett. Friss fagyasztott kadáverfejen a laterális koponyaalapi mútétek is gyakorolhatók. Ugyanakkor az etikai elóírások miatt korlátozott számban lehet hozzájutni a kadáveranyagokhoz [2], az eszközök és a tanfolyamok költségesek, nem zárható ki az átvitt fertőzések lehetősége, és egy anyagon egy bizonyos mútétet csak egyszer lehet kipróbálni.

A fentiek miatt célszerú olyan alternatívát találnunk, amely etikai szempontból nem aggályos, könnyen, több alkalommal, rendszeresen és tervezhetően hozzáférhető, költsége vállalható és kiszámítható mértékú, és valósághứen modellezi a valóságos viszonyokat és az élő páciensen végzett beavatkozásokat.

A műanyagokból készült - nyomtatott vagy öntött 3D modellek [3] mellett ilyen lehetőség még a szimulátor, amely lehetőséget kínál fülmútétek (például mastoidectomia, cochlearis implantáció) virtuális elvégzésére $3 \mathrm{D}$-ben $[2]$.

\section{Anyag és módszer}

A gyakorlati képzés segítésére a Szegedi Tudományegyetem 2019-ben az „EFOP-4.2.2-16-2017-00001: Skill laborok fejlesztése" projekt keretében VOXEL-MAN fül-orr-gégészeti szimulátort helyezett üzembe az Orvosi Készségfejlesztési Központban. A cikk fül-orr-gégész szakorvos szerzői a graduális és posztgraduális képzés oktatói, és különböző szintű gyakorlati tapasztalattal rendelkeznek a fülsebészeti beavatkozások terén. A szerzők a VOXEL-MAN Tempo szimulátor megismerését követően bemutatják a készüléket, és megfogalmazzák a szimulátorral végzett beavatkozásokkal szemben támasztott igényüket. A megfogalmazott szempontoknak megfelelően értékelik a VOXEL-MAN Tempo szimulátort, és meghatározzák, milyen szerepet szánnak neki a gyakorlati képzésben. 


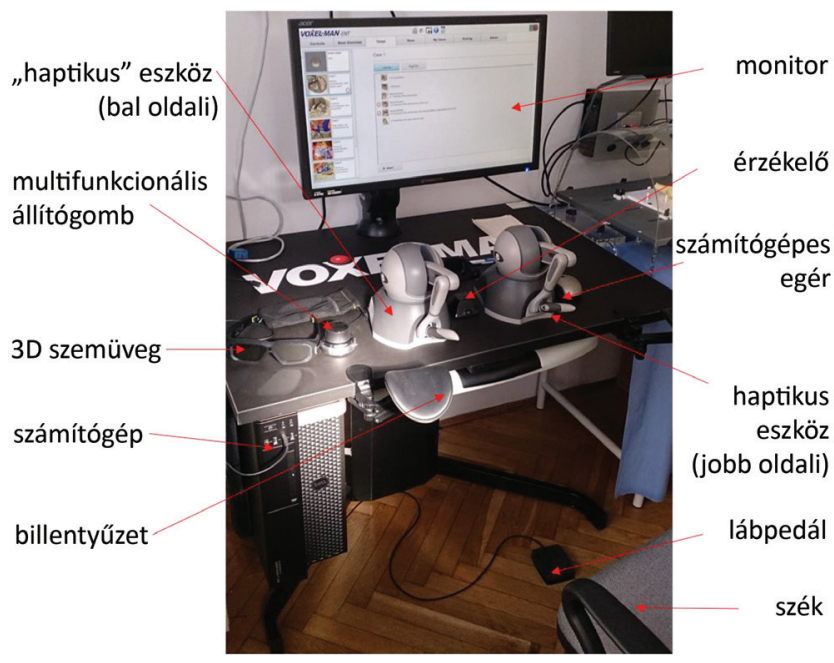

1. ábra

A VOXEL-MAN 3D szimulációs eszköz részei

\section{Eredmények}

A VOXEL-MAN szimulátort a hamburgi HamburgEppendorf Egyetemi Klinikai Központ VOXEL-MAN Munkacsoportja alkotta meg és fejleszti. 2005-ben került bevezetésre a TempoSurg szimulátor, majd 2011ben bemutatták a VOXEL-MAN Tempo nevú csontfúró második generációját [4]. A szimulátor fülsebészeti (Tempo) és orrmelléküreg-sebészeti (Sinus) alprogramokból áll.

A VOXEL-MAN Tempo alprogram fó részei ( 1 . ábra):

1. számítógépasztal, számítógép, monitor, billentyüzet, egér;

2. két darab kartámasz;

3. két darab, ún. haptikus eszköz;

4. lábpedál;

5. multifunkciós állítógomb;

6. érzékelő;

7. 3D szemüveg.

\section{Munkamenet}

A számítógépasztalhoz ülve néhány lépésben, az egér és a billentyüzet segítségével kiválasztjuk a kívánt gyakorlóprogramot, vagy betöltjük saját esetünk képanyagát, és belőle 3D modellt készítünk, amelyet a monitoron jelenítünk meg. Kiválasztjuk, hogy a gyakorlatot végző jobb- vagy balkezes. Az előre telepített gyakorlóprogramok között valódi beteg nagy felbontású CT-vizsgálatából (2. ábra) készített 3D modelleket választhatunk. Kiválaszthatjuk, hogy jobb vagy bal oldali, jól fejlett vagy scleroticus középfül-üregrendszerú vagy cholesteatomás eseten szeretnénk-e gyakorolni [5]. Az előre definiált esetekben a nemes képleteket (például arcideg, chorda tympani, sinus sigmoideus, dura mater, hallócsontok) különböző színekkel jeleníti meg a program (3. ábra).

A gyakorlófeladatokhoz szöveges és képi instrukciót kapunk, és a program mintaként megmutatja, hogy egy gyakorlott fülsebész milyen végeredményt ért el (4.ábra). Alkarunkat egy-egy alkartámasszal támasztjuk alá, így gyakoroljuk a kényelmes és biztonságos mútéti kéz- és kartartást. A multifunkciós állítógomb segítségével a kívánt mikroszkópos nagyítással a kívánt állásba hozzuk a sziklacsontot (3. ábra). Az eszköztárból kiválasztjuk a használni kívánt sebészeti eszközöket, amelyeket a két haptikus eszközzel kezelünk (1. ábra).

A haptikus eszközök olyan kézi darabok, amelyek érzékeltetik a fizikai ellenállást. Szabadon mozgathatók a térben. Fúráskor és szíváskor a valódi sziklacsonton történő fúráshoz hasonló érzést biztosítanak a leadott rezgés és az ellenállás által. Segítségükkel a sziklacsontnak még az egészen kis méretû́ struktúráit is érzékelhetjük [5].

A sebészeti eszköztálcán különböző méretû́ $(0,8-7$ $\mathrm{mm}$ ) és fajtájú (vágó és gyémánt) virtuális fúrók állnak rendelkezésre, amelyeket az egyik kezünkben tartunk (3. ábra). A másik kézben tartott virtuális szívó segítségével gyakorolható a kétkezes munka. A virtuális szívó folyamatosan múködik, míg a fúrót a lábpedállal hozzuk

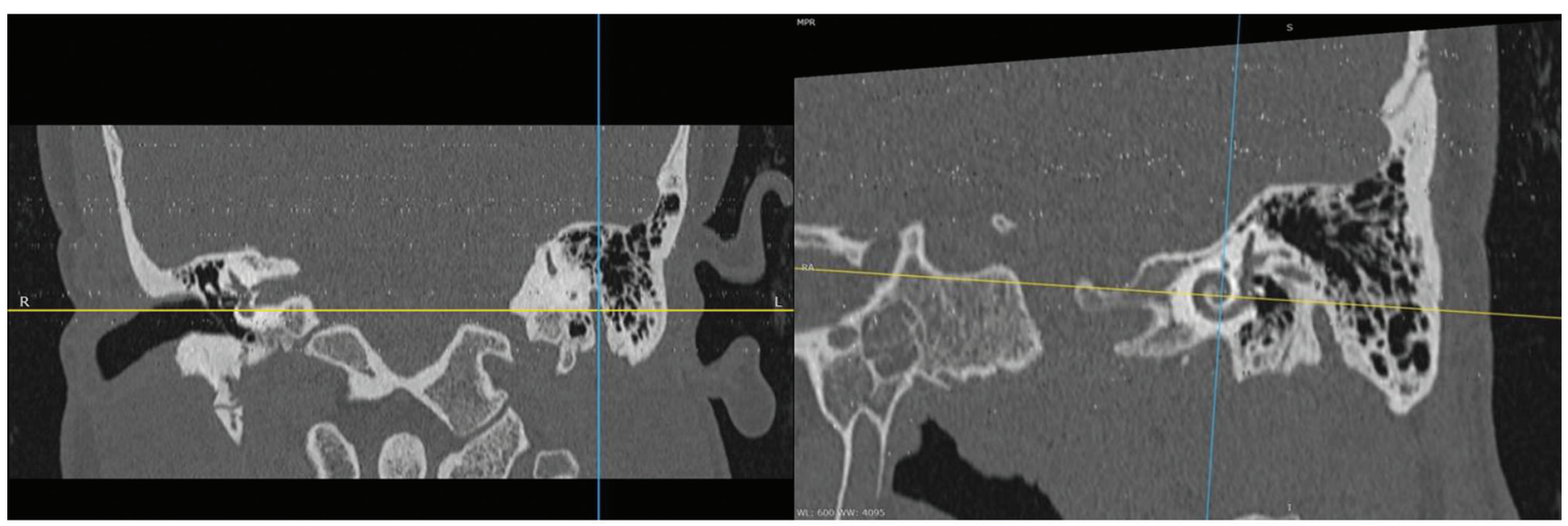

2. ábra

A betegek CT-felvétele betölthető a virtuális sebészeti rendszerbe, és a mútétet így egyénre szabottan, feldolgozás után a szimulátoron végezhetjük el $\mathrm{CT}=$ komputertomográfia 


\section{VOX'ELLMAN ENT}

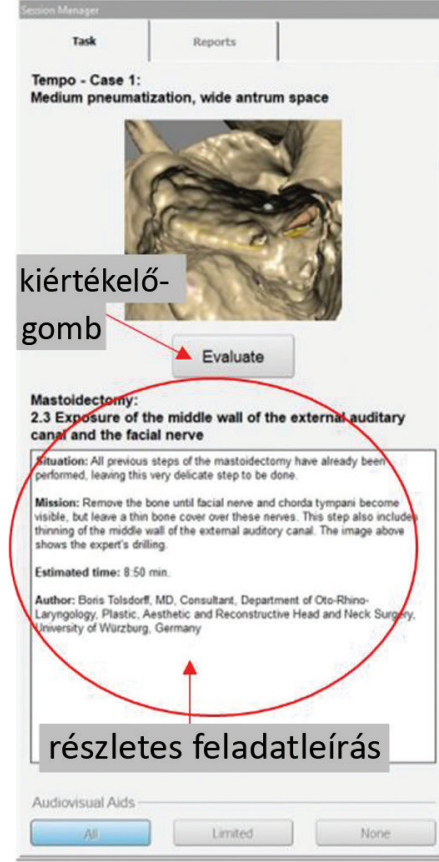

$x[8=$

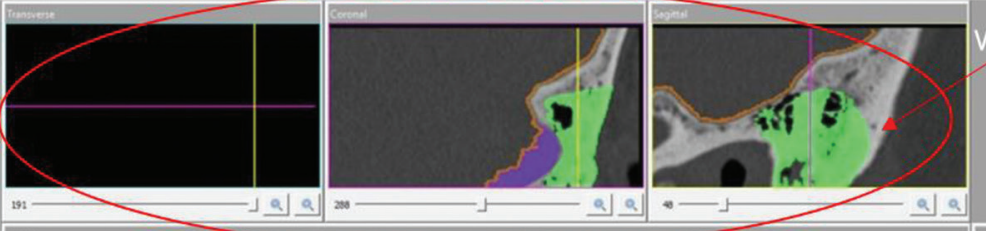

virtuális sebészeti

navigáció,

CT-felvétel

eszköztálca

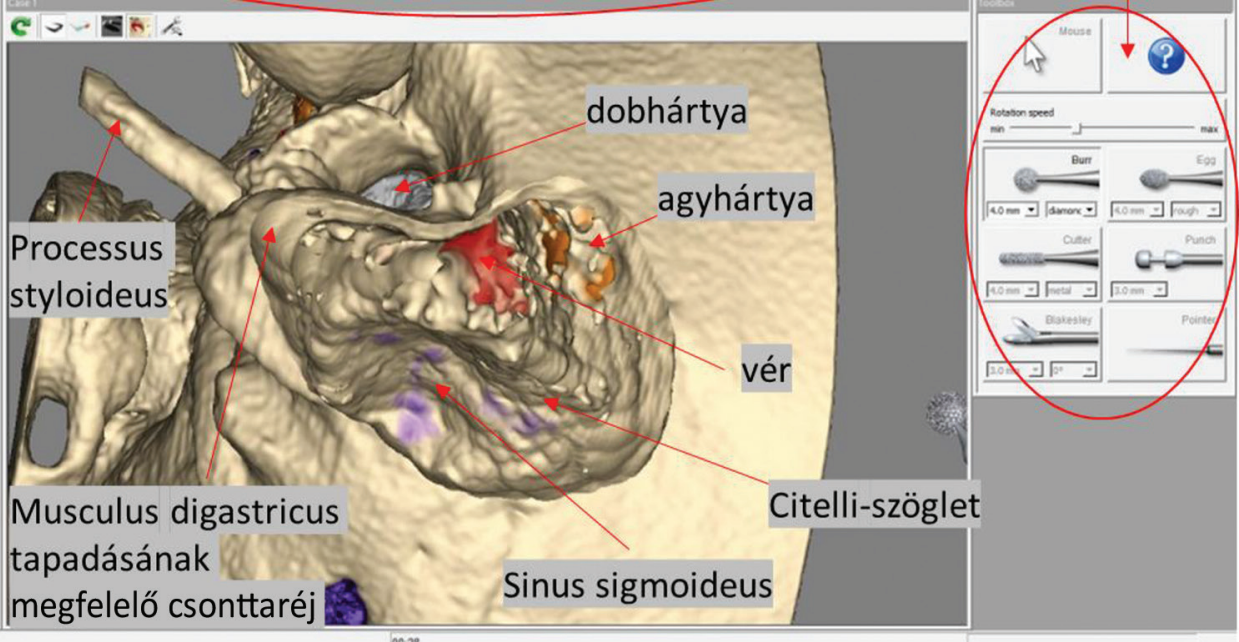

3. ábra Bal oldali sziklacsonton végzett mastoidectomiás üreg. A kép közepén a mastoidectomiás üreget és szkeletonizált határait (agyhártya, sinus sigmoide-
us, Citelli-szöglet, a musculus digastricus tapadásának megfelelő csonttaréj) látjuk. A kép jobb oldalán az eszköztálca (fúrók, fogók, túk) látható. A kép
felsó részén a virtuális navigációs rendszer CT-képei. A kép bal oldalán, a kiértékelés parancsikonja alatt a gyakorlófeladat részletes leírását, instrukció-
kat találunk
CT = komputertomográfia

múködésbe. A beavatkozás során bármikor megállhatunk. A mütéti területet bármilyen szögből, makroszkópos méretben és mikroszkópos nagyításban is szemügyre vehetjük. A virtuális navigációs rendszer a háttérben folyamatosan múködik, így a müszerek a CT-felvétel három ortogonális síkjában mindvégig követhetők a képernyő felső sávjában [5]. Ha manipulációnk kapcsán egy nemes képletet veszélyeztetünk vagy sértünk, arra a szimulátor hangjelzéssel és feliratokkal figyelmeztet: megjelenik a képernyőn a képlet neve, valamint az eszköz és a képlet távolsága milliméterben.
A szerzőknek a szimulátorral végzett beavatkozásokkal szemben támasztott igénye:

1) A fülmútétek, így a cochlearis implantáció csontmunkája reprodukálható módon elvégezhetô a beteg halántékcsontjáról készített rutin, nagy felbontású CT birtokában.

2) Segíti és megtanítja a tájékozódást a sziklacsont bonyolult anatómiai viszonyai között.

3) A sziklacsontot és a benne lévő képleteket virtuálisan, mégis valósághúen mutatja meg.

4) Lehetővé teszi a fülműtét valósághű elvégzését.
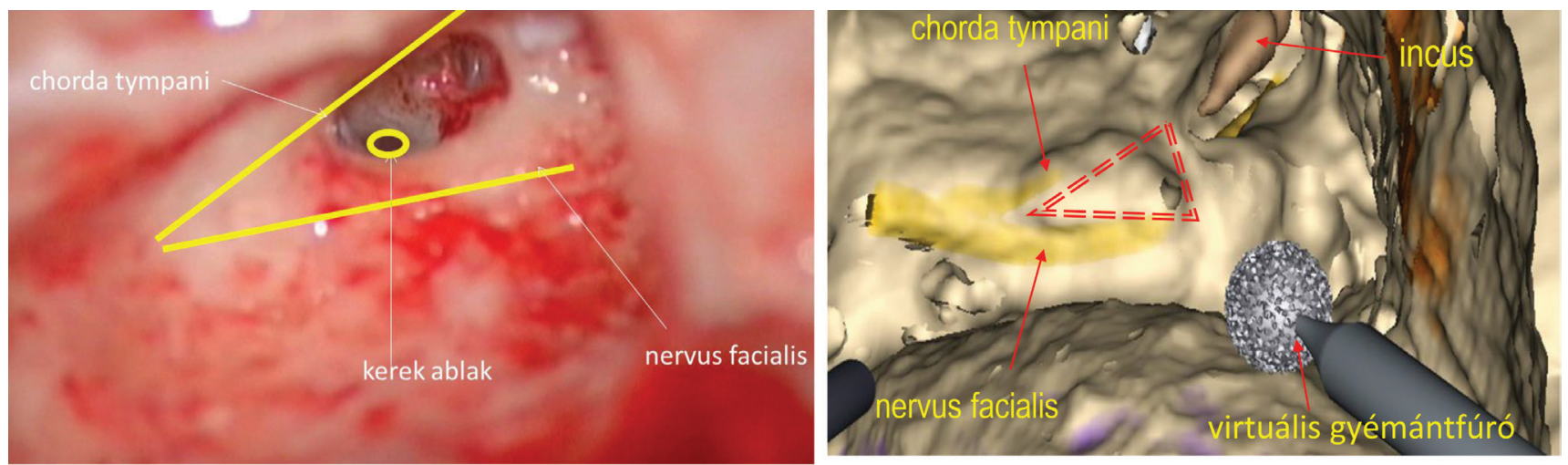

4. ábra

Mastoidectomiát követően végzett posterior tympanotomia a valóságban és a szimulátoron: mikroszkópos mútéti kép (5×-ös nagyítás). A recessus facialis a nervus facialis és a chorda tympani által bezárt háromszög, melynek cranialis szára az incus rövid nyújtványa. A minimálisan invazív cochlearis implantáció során az elektródasor bevezetése a cochlea kerek ablakán keresztül történik 


\section{Megbeszélés}

A virtuális sebészeti szimulátorok új lehetőséget jelentenek a kompetencia- és készségfejlesztés-központú képzésben, mivel ezen eszközök - mindamellett, hogy fejlesztik a kézügyességet és a térlátást - segítséget jelenthetnek a szakspecifikus mútéttípusok lépéseinek elsajátításában és a mútéti anatómiai ismeretek elmélyítésében, valódi anatómiai preparátum nélkül $[6,7]$. A VOXEL-MAN Tempo szimulátor lehetőséget nyújt valósághű modellek és múszerek használatára. Valós páciens nagy felbontású halántékcsont-CT-vizsgálatának adataiból és a kiválasztott müszerekből számítógép készít nagy felbontású modellt, amelyet 3D képernyőre vezetünk ki, így virtuális $3 \mathrm{D}$ modellt kapunk. A virtuális valóság és a robotika technikájának alkalmazása a valós beavatkozást megközelítő, hasonló látványt és érzetet biztosít [5].

A munkaállomás (a készülék és a szék) helyigénye kb. $4 \mathrm{~m}^{2}$, így kis helyiségben is elhelyezhető. Használata sem különleges előkészületet, sem higiénés védőfelszerelést nem igényel. A program lehetővé teszi fülmútétek virtuális elvégzését taktilis visszacsatolással. Az anatómiai képletek egymástól való távolságának mérését és vizualizálását is biztosítja. A VOXEL-MAN Tempo több, előre definiált feladatot kínál, például a sinus sigmoideus és a nervus facialis szkeletonizálását, illetve az incus vizualizálását. Az automatizált értékelőrendszer gyorsan és objektíven értékeli a gyakorlatot végző munkáját, miáltal célzottan fejleszthetők a gyakorlatot végző készségei, és objektivizálható a fejlődés. A gyakorlómunka rögzíthető videófelvételen is, így a gyakorlatot végző és a mentor lépésról lépésre visszanézheti a gyakorlatot, azonosíthatják a hibás mozdulatokat, végül pedig megállapíthatják a fejlődés menetét („learning curve”) [5].

A szimulátor segít a mútét megtervezésében és javítja a sebész gyakorlatát, hiszen ugyanazon az anyagon több alkalommal is elvégezhető ugyanaz a mútét. A virtuális mütét összevethető a betegen végzett mütéttel anatómiai és mütéti szempontok alapján, illetve tudományos publikációk céljából (4. ábra).

Korábbi közleményeinkben már rámutattunk arra, hogy az életkori sajátságok és azon belül az egyéni eltérések miatt kiemelt jelentőséggel bír a preoperatív képalkotás $[8,9]$. A jó minőségü, részletgazdag CT- és 'conebeam' (kúpsugaras) CT-vizsgálat képanyagának alapos áttanulmányozásával a fülsebész átgondolja az egyén anatómiai viszonyait, és mưtéti tervet állít fel, melynek célja a gyors, célratörő, szövődménymentes és a lehető legkisebb megterheléssel járó beavatkozás.

A szimulátor jelentósége, hogy egy beteget a preoperatív CT-képsor betöltésével virtuálisan akár többször is megoperálhatunk az „éles” műtét előtt, ami különösen a rendellenes anatómiai felépítésű esetekben kiemelt jelentőségü. Előre telepített oktatóprogramokkal segíti az egyes sebészi lépések, mưtéti típusok gyakorlását, továbbá az oktatók saját maguk is létrehozhatnak gyakorlófel- adatokat, amelyeken a saját virtuális preparátumukat mutatják be. Megjegyezzük, hogy a virtuális szimulátor kizárólag a csontmunka gyakorlására alkalmas, lágyrészmunka gyakorlására nem.

A speciális műtéti technikák - mint például a cochlearis implantáció - szükségessé teszik a mastoid üreg feltárása után a posterior tympanotomia (a recessus facialisban készített ablak, amelyen keresztül feltárjuk a dobüreget) elvégzését, és az implantátum aktív elektródájának a cochleába juttatását a kerek ablakon vagy a cochlea falán készített ablakon (cochleostomán) keresztül. Különös gondot kell fordítanunk ezen műtéti lépések begyakorlására annak érdekében, hogy kellően nagy feltárást biztosítsunk az elektróda bevezetésének a scala tympaniba, ugyanakkor megőrizzük az arcideget és a chorda tympanit, és ne okozzunk sérülést a kengyelen sem (4. ábra).

A fülmútétek elsajátítására, begyakorlására és a különböző esetek anatómiai és patológiás eltéréseinek megítélésére jelentős gyakorlati időt kell szánni, melyben a tanulási fázisok szerinti elméleti képzésnek és gyakorlati oktatásnak fontos a szerepe.

A gyakorlat megszerzése érdekében kezdetben a nem betegen végzett, megfelelő számú, virtuális 3D szimulátoron végzett mütéteknek, majd a 3D nyomtatott sziklacsonton [10] és a kadáversziklacsonton történő sebészi beavatkozásoknak van a legnagyobb jelentősége [4], csak ezután kerülhet sor a humán mútéti gyakorlat megkezdésére. A 3D virtuális sebészet és a 3D nyomtatás technikai fejlődésével, ezek igen valósághű megjelenésével és manuális kivitelezési opcióval, a gyakorlati sebészi sziklacsontmunka elvégzése megközelíti a kadáveren, valamint a betegen történő mútéti beavatkozást.

Komplex, intenzív fülészeti kurzusok tartására nyílik lehetőség a virtuális sebészeti, szimulátoros 3D technika segítségével, melyet az SZTE-n a közeljövőben rendelkezésre álló 3D nyomtatóval elólllított sziklacsonton végzett mútéttel gyakorolhatunk a kadávermütétek előtt - melyekre egyre kevesebb lehetőség adódik - a minél precízebb technika elsajátítása céljából.

Távlati lehetőségként felmerül a telemedicina, mivel az napjainkban a gyors informatikai fejlődésnek és a széles sávú internetelérhetőségnek köszönhetően egyre nagyobb teret nyer az egészségügyi ellátásban. Fülsebészeti szempontból ideális telemedicinális lehetőség a betegről készült leletek, radiológiai képfelvételek (CT, MRI) előzetes referálása a szakcentrumok felé, amelyekkel már a személyes találkozás előtt is megállapítható a szükséges beavatkozás jellege és az ellátás időtartama [10].

Ezen telereferáló rendszerek új irányát és kiegészítését jelenthetik a virtuális sebészi szimulátorok is. Mivel a távdiagnosztikával készült leleteket felhasználva előzetesen, virtuálisan megtervezhetjük és elvégezhetjük a mütéteket, a fülsebészek - akár kezdők, akár rutinosak is előre felkészülhetnek egy-egy esetre. 
Arora és mtsai tanulmányukban kadáversziklacsontokról készült CT-felvételek alapján készítettek virtuális modelleket, majd ezek előzetes operációja után végezték el a valóságos beavatkozást. Kutatásaikban úgy találták, hogy ez a metodika javítja az egyénre szabott ellátást, a mütéti tervezést, és segíti a sebészi képzést [11].

\section{Következtetés}

A sebészeti virtuálisvalóság-szimulátorral szerzett elsó tapasztalataink szerint a VOXEL-MAN Tempo 3D teljesíti a szerzőknek a szimulátorokkal szemben támasztott igényeit:

1) A fülmütétek, így a cochlearis implantáció csontmunkája reprodukálható módon elvégezhető a beteg halántékcsontjáról készített rutin, nagy felbontású CT birtokában. 2) Feliratokkal és hangjelzés leadásával segíti a tájékozódást a sziklacsont bonyolult anatómiai viszonyai között, továbbá megadja a sebészi eszköz és a szövődmény szempontjából fontos, az eszköz közelében lévó képlet távolságát, illetve anatómiai képletek távolságának mérését és vizualizálását is. A mütéti területen történő tájékozódást virtuális navigációs rendszer segíti a CTvizsgálat három ortogonális síkjában. 3) A sziklacsontot és a benne lévő képleteket virtuálisan, ugyanakkor valósághüen mutatja meg. 4) A rendszer lehetővé teszi a fülmútét valósághü elvégzését (kétkezes csontmunka fúróval és szívóval, vérzés szimulálása) taktilis „feedback” lehetőségével. 5 ) Lágyrész-munka gyakorlására nem alkalmas.

Mindezek alapján a Szegedi Tudományegyetem Általános Orvostudományi Karán rendelkezésre álló virtuális rendszernek a fül-orr-gégészeti (fülészeti) graduális és a posztgraduális képzésben is fontos szerepet szánunk.

Anyagi támogatás: A közlemény megírása, illetve a kapcsolódó kutatómunka anyagi támogatásban nem részesült.

Szerzői munkamegosztás: P. Á., P. B., Cs. M.: A szakirodalom áttekintése, kigyújtése, elemzése, a szimulátor kipróbálása. Sz. L., T. Z.: A szimulátor kipróbálása. J. Gy., D. B., N. R.: A szakirodalom áttekintése, a kézirat meg- szövegezése. B. Zs., K. J. G., R. L.: A kézirat szakmai véleményezése. A cikk végleges változatát valamennyi szerző elolvasta és jóváhagyta.

Érdekeltségek: A szerzőknek nincsenek érdekeltségeik.

\section{Irodalom}

[1] George AP, De R. Review of temporal bone dissection teaching: how it was, is and will be. J Laryngol Otol. 2010; 124: 119-125.

[2] Frithioff A, Sørensen MS, Andersen SA. European status on temporal bone training: a questionnaire study. Eur Arch Otorhinolaryngol. 2018; 275: 357-363.

[3] Rose AS, Kimbell JS, Webster CE, et al. Multi-material 3D models for temporal bone surgical simulation. Ann Otol Rhinol Laryngol. 2015; 124: 528-536.

[4] Leuwer R, Petersik A, Pflesser B, et al. VOXEL-MAN TempoSurg - a virtual reality temporal bone surgery simulator. J Jpn Soc Head Neck Surg. 2007; 17: 203-207.

[5] Voxel-Man Tempo. June 1, 2020. Available from: https://www. voxel-man.com/simulators/tempo/ [accessed: November 1, 2020].

[6] Kashikar TS, Kerwin TF, Moberly AC, et al. A review of simulation applications in temporal bone surgery. Laryngoscope Investig Otolaryngol. 2019; 4: 420-424.

[7] Frithioff A, Frendø M, Mikkelsen PT, et al. Ultra-high-fidelity virtual reality mastoidectomy simulation training: a randomized, controlled trial. Eur Arch Otorhinolaryngol. 2020; 277: 13351341.

[8] Posta B, Jarabin JA, Perényi Á, et al. Pediatric hearing rehabilitation with the Baha ${ }^{\circledR}$ Attract implant system. [Fiatalkori hallásrehabilitáció Baha ${ }^{\circledast}$ Attract implantátumrendszerrel.] Orv Hetil. 2017; 158: 304-310. [Hungarian]

[9] Perényi Á, Jóri J, Csanády M, et al. Dimensions of the human temporal bone that are relevant to cochlear implantation surgery in infants and toddlers: a clinical-radiological study. [Az emberi halántékcsontnak a csecsemő- és kisgyermekkori cochlearis implantáció szempontjából kiemelkedóen fontos dimenziói. Klinikoradiológiai vizsgálat.] Orv Hetil. 2019; 160: 936-943. [Hungarian]

[10] Kokesh J, Ferguson AS, Patricoski C. Preoperative planning for ear surgery using store-and-forward telemedicine. Otolaryngol Head Neck Surg. 2010; 143: 253-257.

[11] Arora A, Swords C, Khemani S, et al. Virtual reality case-specific rehearsal in temporal bone surgery: a preliminary evaluation. Int J Surg. 2014; 12: 141-145.

(Posta Bálint dr.,

Szeged, Tisza Lajos krt. 111., 6725 e-mail: posta.balint@med.u-szeged.hu)

A cikk a Creative Commons Attribution 4.0 International License (https://creativecommons.org/licenses/by/4.0/) feltételei szerint publikált Open Access közlemény, melynek szellemében a cikk bármilyen médiumban szabadon felhasználható, megosztható és újraközölhető, feltéve, hogy az eredeti szerző és a közlés helye, illetve a CC License linkje és az esetlegesen végrehajtott módosítások feltüntetésre kerülnek. (SID_1) 